\title{
Biogas Production from Water Spinach and Banana Peel Waste Using Plug Flow Reactor
}

\author{
Soeprijanto Soeprijanto ${ }^{1 *}$, Alif Adi Kaisar ${ }^{1}$, Dyah Firdha Amalia ${ }^{1}$
}

\begin{abstract}
Biofuel is one of the promising energy in the future that can play an essential role in maintaining energy security in Indonesia Biogas, which is only one of many types of biofuels is considered a renewable energy source that does not contribute to the impact of greenhouse gases. The main composition of the gas consists mainly of methane $\left(\mathrm{CH}_{4}\right)$, and carbon dioxide $\left(\mathrm{CO}_{2}\right)$ and resembles commonly used fossil fuels such as natural gas. This study aimed to determine the method of making biogas using water spinach and banana peel waste. The process of making biogas begins with preparing the materials to be fed to the bioreactor daily. The prepared material is put into the bioreactor continuously every 24 hours. The results obtained are the $\mathrm{C} / \mathrm{N}$ content of water spinach 10 while the banana peel is 42 . The $\mathrm{C} / \mathrm{N}$ ratio affects biogas production. The maximum production of biogas accumulation is in water spinach as raw material. On water spinach, the yield was 287.825 $\mathrm{l} / \mathrm{kg}$ substrate and the average volume per day was $17.989 \mathrm{l} / \mathrm{kg}$ substrate. The banana peel yields $46,184 \mathrm{l} / \mathrm{kg}$ of the substrate and the average volume per day is $2,887 \mathrm{l} / \mathrm{kg}$ of the substrate. Based on the flame test conducted at the beginning of the week the gas produced can be burned, this occurs in all raw materials.
\end{abstract}

Keywords - Biogas, Water spinach, Banana peel, Organic waste

\section{INTRODUCTION}

B iofuel is one of promising energy in the future that can play an important role in maintaining energy security in Indonesia. Recently, biofuel production is increasing in number to be explored and used as new renewable fuel to replace fossil fuels, especially for transportation purposes [1]. On the other hand, Biogas, which is only one of many biofuels, can be used directly for heating or the production of electricity in generators.

Biogas is one alternative energy source that is growing rapidly in the last decade [2]. Biogas production using anaerobic digestion (AD) technology is still an interesting topic in the effort to address environmental problems as well as harvesting renewable energy [3]. AD is one of the important factors in biogas production. AD has many types with their respective specifications to suit the circumstances [4]. Biogas is produced during the degradation of organic matter by microorganisms in an anoxic environment, which is commonly referred to as the Anaerobic Digester (AD) process. Usually, this process involves the production of a biogas mixture consisting mainly of $\mathrm{CH} 4(60 \%), \mathrm{CO} 2(35-40 \%)$, and other residual gases such as $\mathrm{H} 2, \mathrm{NH} 3$, and $\mathrm{H} 2 \mathrm{~S}$ (depending on the source of organic material used) [3]. Inside it is also saturated with water and water vapor. Gas composition varies based on feed and other factory operating conditions [5].

Food waste is an excellent substrate for producing biogas with high methane conversion. However, the use of food waste as a substrate can cause an imbalance in the rapid decomposition process and is not consumed quickly by methanogens. Banana peel is a lot of waste from bananas. Generally, banana peels have not been used, only disposed of as organic waste or used as fodder for livestock such as goats, cows, and buffalo. Banana peels still have not received adequate treatment because banana waste still contains high enough starch, protein, and fiber. After all, it is known that in general, the thickness of banana peels is 41 parts of the fruit, therefore an effort is needed to utilize it [6].

Water spinach is a vegetable that humans widely consume because it contains minerals and vitamins that are very important for human health. In addition to containing vitamins and minerals, this plant contains sufficient nitrogen. Because it contains nitrogen, water spinach can be used as raw material for biogas production, by utilizing the accumulated leftovers of water spinach vegetables from market activities. Nitrogen is the main food source for anaerobic bacteria, so the optimum growth of bacteria is strongly influenced by this element. A good ammonia nitrogen concentration ranges from $200-1500 \mathrm{mg} / \mathrm{lt}$ and if it exceeds $3000 \mathrm{mg} / \mathrm{lt}$ it will be toxic. Besides having nitrogen content, water spinach also contains cellulose, and cellulose is found naturally, especially in plant cell walls which make up 35\%-50\% of the total dry weight of plants. Other components consist of 20\%-35\% hemicellulose and 5\%-30\% lignin [7].

Substrate composition is very important for microorganisms in the biogas process and also for process stability and gas production. The substrate must meet the nutritional needs of microorganisms, both in terms of energy sources and various components needed to build new cells. In the case of the decomposition of organic matter in the biogas process, the ratio of carbon to nitrogen $(\mathrm{C} / \mathrm{N}$ ratio) is also considered to be very important. The ratio mustn't be too low, in other words, there is not too much nitrogen compared to carbon. If so, the process can easily suffer from ammonia inhibition. The ratio should also not be too high, as the bacteria in the process may experience a nitrogen deficiency. It is difficult to say exactly what optimal ratio is as it varies with different substrates androcess conditions [8].

Anaerobic co-digestion treats different organic substrates mixed and treated together in the biogas process, which gives higher methane yields. The amount of biogas produced per unit of organic matter fed is greater than when each was fed into the digester separately [9]. Co-digestion is the main factor such as

\footnotetext{
${ }^{1}$ Departement of Industrial Chemical Engineering, Institut Teknologi Sepuluh Nopember (ITS), Kampus ITS Keputih Sukolilo, Surabaya, 60111, Indonesia. E-mail soeprijanto@ chem-eng.its.ac.id
} 
pretreatment and digester type to influence biogas production. Two or more organic matter must be managed properly during co-digestion to increase biogas production compared to mono-digestion substrates. Codigestion can increase biogas production from $25 \%$ to $400 \%$ more than mono-digestion from the same substrate [10].

This paper presents a case study to investigate the potential substrates (swamp water spinach or banana peel waste) to produce biogas. This study also aims to find an effective method for processing waste into biogas so that people can easily apply it.

\section{METHOD}

\section{A. Materials}

The feedstock used in this experiment was as follows: wastes of banana peel from banana bread home industry and water spinach from the campus of Institut Teknologi Sepuluh Nopember, Surabaya. Cow dung used as a starter was obtained from the farm. The raw material is weighed as much as $2 \mathrm{~kg}$, cut into small pieces, then ground. Then water is added to a volume of 8 liters.

\section{B. $\quad$ Method}

In this experiment, a certain amount of cow dung was used as an inoculum, mixed with water in a volume ratio of 1:2 introduced to the reactor. The substrate's starter was then left for 7 days and observed biogas production. And then water spinach (WS) and banana peel (BP) ground to the reactor.

TABLE 1.

DIFFERENCE SUBSTRATES, MASS RATE, AND VOLUME

\begin{tabular}{cccc}
\hline \hline Substrate & $\begin{array}{c}\text { Mass rate } \\
\text { (kg/day) }\end{array}$ & $\begin{array}{c}\text { Volume rate } \\
\text { (l/day) }\end{array}$ & $\begin{array}{c}\text { WS:BP } \\
\text { (mass ratio) }\end{array}$ \\
\hline WS & 2 & 8 & $100: 0$ \\
BP & 2 & 8 & $0: 100$ \\
WS-BP & 2 & 8 & $50: 50$ \\
\hline \hline
\end{tabular}

\section{Experimental Setup}

A schematic diagram of an anaerobic digester is shown in Figure 1. The digester was made from stainless steel with an effective volume of $1251(40 \mathrm{~cm} \mathrm{D} \times 100 \mathrm{~cm} \mathrm{~L})$ and was equipped with a flat stirrer $(10 \mathrm{~cm} \mathrm{~W} \times 15 \mathrm{~cm} \mathrm{~L}$ $\times 2 \mathrm{~cm} \mathrm{~T}$ ) to get a homogeneous slurry and to prevent biogas from being trapped in the slurry [10]. Operating conditions were conducted at room temperature. The digester was constructed for continuous mode, the feedstock flow rate was 8 1/day for 24 days. The thermometer and biogas pipe were located at the top of the digester. The motor was installed automatically to move the stirrer for $60 \mathrm{~min}$ and stop for $30 \mathrm{~min}$.

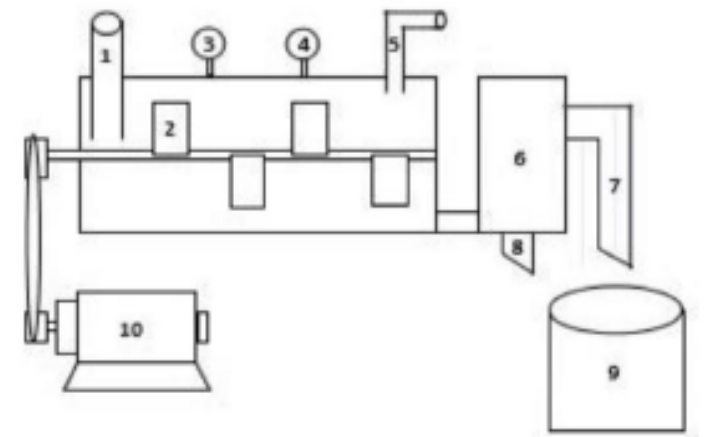

Figure 1. Schematic diagram of plug flow reactor. Note: $1=$ input (feedstock); 2 = stirrer; $3=$ pressure parameter; $4=$ temperature parameter; $5=$ valve output gas; $6=$ digestate collection; $7=$ output effluent; $8=$ disposal valve; $9=$ digestate collection; $10=$ motor

\section{Flame test}

The gas that has been accommodated is connected to a plastic hose, then the end of the hose is ignited at the source of the fire.

\section{RESULTS AND DISCUSSION}

\section{Effect of C/N Ratio on Raw Materials}

Table 2. shows that the raw material for biogas from water spinach has a $\mathrm{C}$ content of $49.20 \%$ while the $\mathrm{N}$ content is $4.77 \%$ so it has a $\mathrm{C} / \mathrm{N}$ ratio of 10 . While the raw material for banana peels has a C content of $49.12 \%$ and a content of $\mathrm{N}$ is $1.158 \%$ so that the results of the $\mathrm{C} / \mathrm{N}$ ratio are 42 . The significant difference in the $\mathrm{C} / \mathrm{N}$ ratio will affect the yield of biogas. Other literature shows that the best $\mathrm{C} / \mathrm{N}$ ratio is 30 [1].

High amount of $\mathrm{C}$ content will cause a high formation of carbon dioxide (CO2). Meanwhile, high amount of $\mathrm{N}$ content will also cause high formation of ammonia which adversely affects the survival of microorganisms [11].

$$
\text { TABLE } 2 .
$$

DIFFERENCE SUBSTRATES, MASS RATE, AND VOLUME

\begin{tabular}{cccc}
\hline \hline Substrate & \% C & \% N & \% MC \\
\hline WS & 49.20 & 4.77 & 89.02 \\
BP & 49.12 & 1.158 & 82.91 \\
\hline
\end{tabular}

\section{Effect of Raw Materials on Biogas Production}

The figure below shows the experiment was conducted on a plug flow reactor for 15 days. In these studies, digestion was carried out by a mono variety of feedstock (Table 1). The feedstock was fed into the anaerobic digester at a concentration of $2 \mathrm{~kg} / 81(0.25 \mathrm{~kg} / \mathrm{l})$.

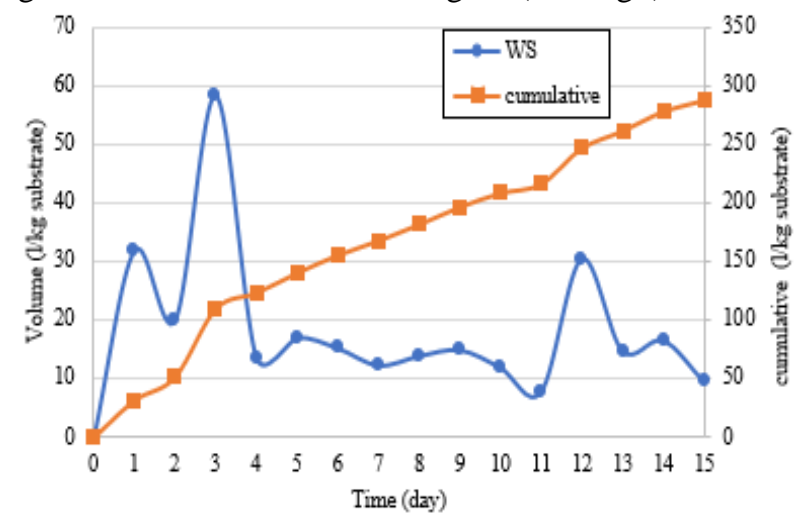

Figure 2. Daily biogas production and cumulative production from water spinach (WS) 
Figure 2 shows an increase and decrease in gas volume per day. The accumulated gas volume was $287.825 \mathrm{l} / \mathrm{kg}$ substrate. From the figure, it can be described that the results obtained are not stable. Steady-state conditions occur where the biogas produced have approximately the same volume so that the line obtained is constant and does not fluctuate. Water Spinach (WS) has a fairly high biogas yield. The average volume produced per day is $17.989 \mathrm{l} / \mathrm{kg}$ substrate. Optimum volume was obtained on the $3^{\text {rd }}$ day. This result is higher compared to other studies [12] that showing the optimum yield of biogas from water spinach is on the $8^{\text {th }}$ day with an average volume of 1800 $\mathrm{ml}$ per day. According to the [12], this is due to the pretreatment condition of the different materials have been carried out.

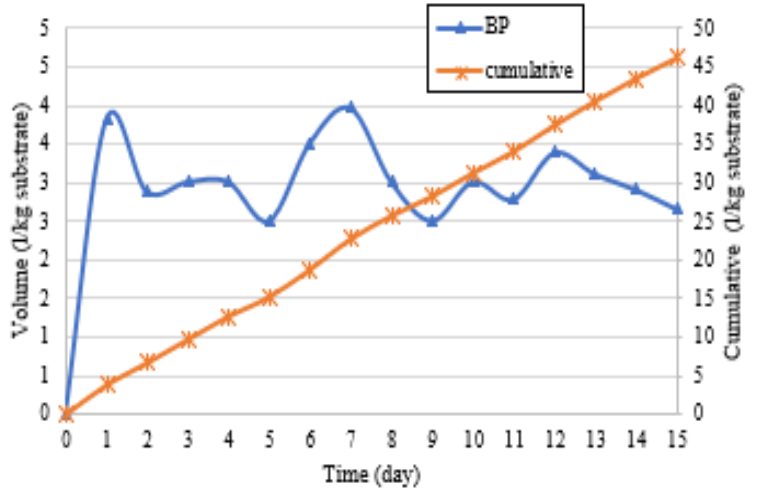

Figure 3. Daily biogas production and cumulative production from the banana peel (BP)

Figure 3 has an increase and decrease in gas volume per day. The accumulated gas volume was $46,184 \mathrm{l} / \mathrm{kg}$ substrate. From the graph, it can be concluded that the results obtained are not steady-state. Meanwhile, according to the literature [13], biogas from banana peels is only obtained on the 3rd day and will continue to increase until the 35th day. This indicates that the biogas yield from banana peels is greater. It is believed that the best part of the banana tree for producing biogas is the banan's peel and flesh. [13].

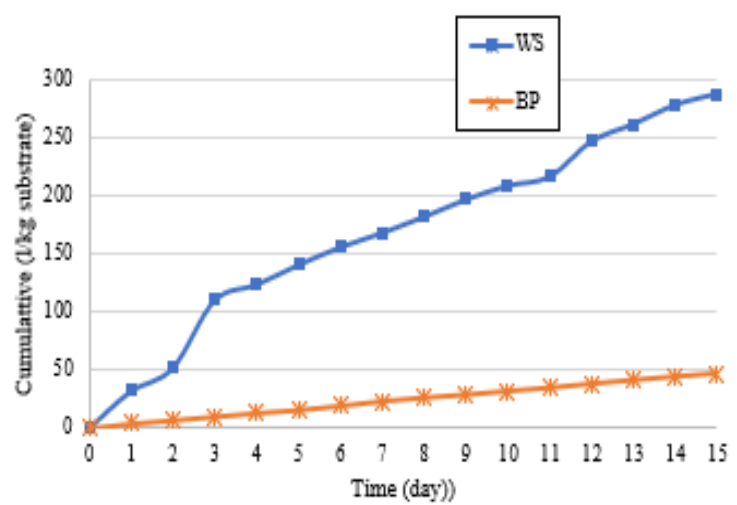

Figure 4. Difference cumulative of water spinach (WS) and banana peel (BP)

Figure 4 shows the cumulative biogas of Water Spinach (WS) and Banana Peel (BP). Accumulatively, the highest biogas production was obtained from water spinach as raw material. The total biogas production from water spinach and banana peels were 287.825 and $46.184 \mathrm{l} / \mathrm{kg}$ of the substrate, respectively. And it can be concluded that the largest total biogas production lies in the raw material of water spinach.

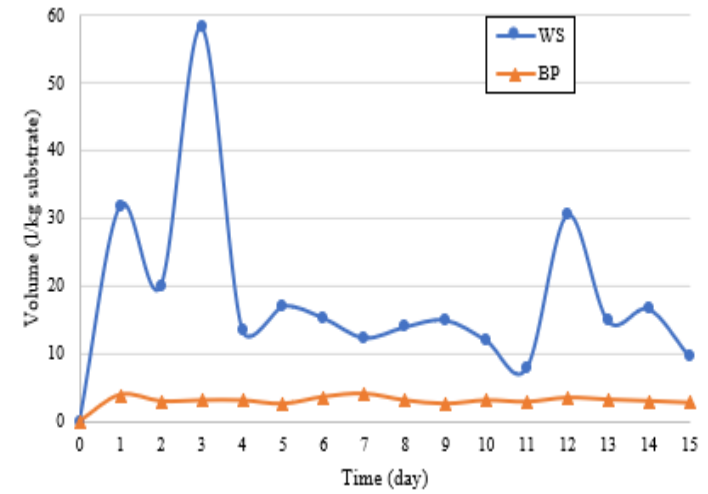

Figure 5. Difference daily volume of water spinach (WS) and banana peel (BP)

Figure 5 shows a very significant volume difference between the two raw materials used. Water Spinach (WS) produces the most biogas of the two raw materials. Meanwhile, banana peels produce the least amount of biogas. Water spinach can produce an average of biogas $17.898 \mathrm{l} / \mathrm{kg}$ substrate daily, then banana peels produce an average of biogas $2.887 \mathrm{l} / \mathrm{kg}$ substrate.

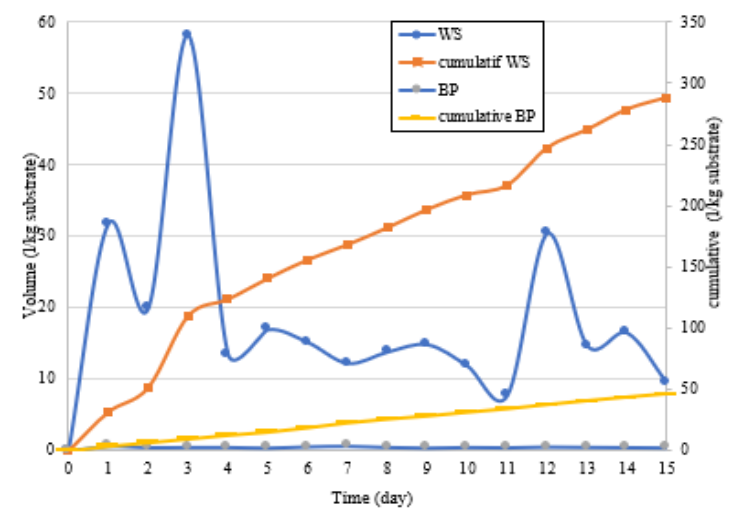

Figure 6. Difference daily volume of water spinach (WS) and banana peel (BP)

Figure 6 shows differences in volume and accumulation of water spinach and banana peels. The resulting biogas production is very significant for water spinach compared to banana peel. This is influenced by the different content of organic compound ineach raw material. The formation of methane gas $(\mathrm{CH} 4)$ requires the element carbon. Carbon elements can be found from carbohydrates which will be used in the acidogenesis process. While microorganisms need the nitrogen element for cell formation. From the raw materials of water spinach and banana peels, the $\mathrm{C} / \mathrm{N}$ ratios obtained are 10 and 42 . Other literature shows that the best $\mathrm{C} / \mathrm{N}$ ratio is 30 [11].

\section{Flame Test}

The flame test is carried out to determine whether the biogas produced in the fermentation process contains methane gas or not so that it can be used as a substitute for kerosene and LPG. Biogas is said to be successful in that there is methane gas marked in blue in the flame. The color of the fire indicates the level of heat of the fire and the contents of the burning content [14]. Based on the flame test conducted at the beginning of the week the gas produced can be burned, this occurs in all raw materials. The reason for this is because the production of methane 
gas produced at the beginning of biogas production is already high. After all, the anaerobic process runs properly.

The gas that has been accommodated is connected to a plastic hose, then the end of the hose is ignited at the source of the fire. This aims to determine whether there is methane gas content in the biogas fermentation process. Flame is one indicator of the success or failure of the biogas fermentation process. The final result expected from the biogas process is to produce a blue flame so that when used in everyday life, the users will feel the benefits.

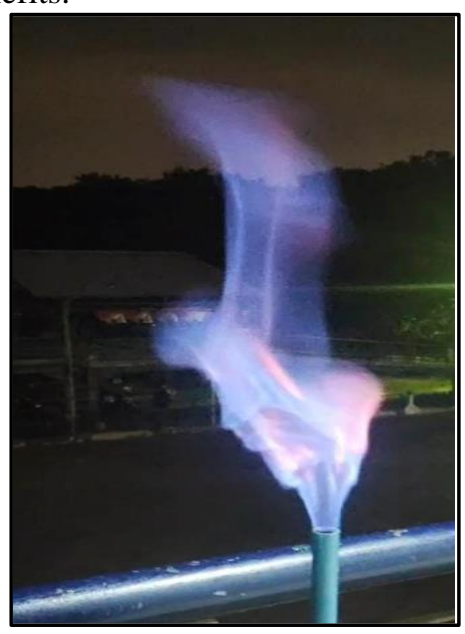

Figure 7. Flame Test

The biogas flame from all treatments produces a blue flame, this indicates the formation of methane gas (CH4) has a gas content above $40 \%$. If the gas produced from the anaerobic process is combustible, it may contain $45 \%$ methane gas [15].

\section{Composition of Biogas Production}

The composition of biogas production was different, this was because the composition was influenced by the use of raw material. In this experiment the biogas was produced from WS was CH4 (43,85\%), CO2 (23.67\%),.

\section{CONCLUSION}

From the result obtained, it can be concluded that the best raw material used to produce biogas is water spinach. The biogas was produced with an accumulation of $287.825 \mathrm{l} / \mathrm{kg}$ of the substrate with an average volume of $17.898 \mathrm{l} / \mathrm{kg}$ of the substrate. While, the raw material for banana peel has an accumulation of $46,184 \mathrm{l} / \mathrm{kg}$ of the substrate. The different in the $\mathrm{C} / \mathrm{N}$ ratios also play crucial factor in biogas production.

\section{ACKNOWLEDGMENTS}

The authors would like to thank the Department of Industrial Chemical Engineering, Faculty of Vocational Studies, Institut Teknologi Sepuluh Nopember (ITS), Surabaya, Indonesia for providing financial support through this research, in the year 2021.

\section{REFERENCES}

[1] Soeprijanto, Teknologi Biogas Sebagai Energi Terbarukan, Surabaya: ITS Press, 2019.

[2] A. Bayuseno, "PENERAPAN DAN PENGUJIAN MODEL TEKNOLOGI ANAEROB DIGESTER UNTUK PENGOLAHAN SAMPAH BUAH-BUAHAN DARI PASAR TRADISIONAL," ROTASI, vol. 11, no. 2, pp. 5-10, 2009.

[3] Y. Jin, T. Chen, X. Chen, and Z. Yu., "Life-cycle assessment of energy consumption and environmental impact of an integrated food waste-based biogas plant," Applied Energy, vol. 151, pp. 227-236, 2015.

[4] Y. Qian, S. Sun, D. Ju, X. Shan and X. Lu, "Review of the state-of-the-art of biogas combustion mechanisms and applications in internal combustion engines," Renewable and Sustainable Energy Reviews, vol. 69, pp. 50-58, 2017.

[5] V. S. Ksdirsagar, P. Pawar and S. Mehetre, "Holistic Approach for Biogas Technology Implementation to Improve Sustainability," Current Science, vol. 2, p. 116, 2019.

[6] V. Fitria, Karakteristik Pektin Hasil Ekstraksi dari Limbah Kulit Pisang Kepok, Jakarta: FKIK, 2013.

[7] Y. B. Nitbani, B. V. Tarigan and J. U. Jasron, "Pengaruh Perbandingan Komposisi Campuran Perut Ikan, Kangkung dan Feses Babi terhadap Ph, Kuantitas dan Kualitas Biogas," Lontar Jurnal Teknik Mesin UNDANA, vol. 03, no. 02, pp. 5768, 2016.

[8] H.-W. Yen and D. E. Brune, "Anaerobic co-digestion of algal sludge and waste paper to produce methane," Bioresource Technology, vol. 98, no. 1, pp. 130-134, 2008.

[9] C. Cavinato, F. Fatone, D. Bolzonella and P. Pavan, "Thermophilic anaerobic co-digestion of cattle manure with agro-wastes and energy crops: Comparison of pilot and full scale experiences," Bioresource Technology, vol. 101, pp. 545550, 2010.

[10] I. A. Raja and S. Wazir, "Biogas Production: The Fundamental Processes," Universal Journal of Engineering Science 5(2), pp. 29-37, 2017.

[11] M. Cuetos, X. Gomez, M. Otero and A. Moran, "Anaerobic digestion of solid slaughterhouse waste (SHW) at laboratory scale : influence of co-digestion with the organic fraction of municipal solid waste (OFMSW)," Biochem.Eng Journal, vol. 40, pp. 99-106, 2008.

[12] S. Soeprijanto, D. Prajitno, B. Setiawan, W. Maghfiroh and R. Rohmawati, "Biogas production from co-digestion of water hyacinth, banana peel and water spinach wastes using a horizontal anaerobic digester," Earth and Environmental Science, vol. 649, 2019.

[13] A. Hidayat, K. Cahyari and D. R. Sawitri, "PENGEMBANGAN TEKNOLOGI PEMBANGKITAN BIOGAS DARI LIMBAH TANAMAN PISANG (BONGGOL, BATANG, PELEPAH DAUN,KULIT PISANG, PISANG TIDAK LAYAK JUAL, DAN LAINLAIN) UNTUK MEMENUHI KEBUTUHAN BAHAN BAKAR RUMAH TANGGA," Prosiding InSINas, pp. 99103, 2012.

[14] H. Kurniawan and S. Lestari, "Potensi Biogas dari Limbah Jeroan Ikan Patin (Pangasius sp.) Dan Campuran Kiambang (Salvinia Molesta) Secara Anaerob Batch," Jurnal Teknologi Hasil Perikanan, vol. 5, no. 1, pp. 43-51, 2016.

[15] D. Sanjaya, T. and A. Hariyanto, "PRODUKSI BIOGAS DARI CAMPURAN KOTORAN SAPI DENGAN KOTORAN AYAM," Jurnal Teknik Pertanian Lampung, pp. 127-136, 2015. 